Walisongo: Jurnal Penelitian Sosial Keagamaan

Vol. 28 No. 1 (2020) pp. 49-64

DOI: $10.21580 /$ ws.28.1.5978

\title{
Fostering Religious Tolerance in West Papua: A Case Study of Muhammadiyah's Higher-educational Institutions
}

\author{
Muhaiminah Akib, ${ }^{1 *}$ Rezkiah Hartanti, ${ }^{2}$ Hermanto Suaib ${ }^{3}$ \\ ${ }^{1,2,3}$ Universitas Muhammadiyah Sorong, Indonesia
}

\begin{abstract}
This study aims to identify the role of Muhammadiyah's highereducational institutions in fostering religious tolerance in West Papua. Applying the qualitative method, this research is conducted in three Muhammadiyah higher-educational institutions in West Papua i.e., Universitas Muhammadiyah Sorong (UM Sorong) Sorong City, Universitas Pendidikan Muhammadiyah Sorong (UNIMUDA) Sorong Regency, and Sekolah Tinggi Keguruan dan Ilmu Pendidikan (STKIP) Muhammadiyah Manokwari. The results showed that Muhammadiyah's higher-educational institutions are inclusive in terms of spiritual understanding. In fostering religious tolerance there are three approaches taken by the three Muhammadiyah higher-educational institutions in West Papua: 1) social approach, 2) cultural approach, and 3) excellent service approaches. The strategies implemented the role includes: 1) disseminating Muhammadiyah's vision and mission, 2) inculcating tolerance values since the beginning of students joining Muhammadiyah higher-educational institutions, 3) strengthening tolerance value by lecturing processes, conducting, sharing sessions both formally and informally, and 4) empowering student activity units and other facilities that support multicultural student interaction processes.
\end{abstract}

Penelitian ini bertujuan untuk mengidentifikasi peran perguruan tinggi Muhammadiyah dalam mempertahankan toleransi beragama di Papua Barat. Dengan menggunakan metode kualitatif, penelitian ini dilaku-

*Corresponding Author: Muhaiminah Akib (mina.akib@gmail.com), Jl. Klamono Km. 17, Klablim Sorong, Papua Barat, Indonesia 98417.

ISSN 0852-7172 (p) 2461-064X (e)

(C) 2020 by the Authors, published by Walisongo: Jurnal Penelitian Sosial Keagamaan https://journal.walisongo.ac.id/index.php/walisongo 
kan di tiga perguruan tinggi Muhammadiyah di Papua Barat, yaitu: Universitas Muhammadiyah Sorong (UM Sorong) Kota Sorong, Universitas Pendidikan Muhammadiyah Sorong (UNIMUDA) Kabupaten Sorong dan Sekolah Tinggi Keguruan dan Ilmu Pendidikan (STKIP) Muhammadiyah Manokwari. Hasil penelitian menunjukkan bahwa, dalam mempertahankan toleransi agama, ada tiga pendekatan yang dilakukan oleh tiga perguruan tinggi Muhammadiyah di Papua Barat, yaitu: 1) pendekatan sosial, 2) pendekatan budaya, dan 3) pendekatan pemberian layanan prima. Strategi dilakukan untuk mewujudkan peran ini meliputi: 1) menyebarluaskan visi dan misi Muhammadiyah, 2) menanamkan nilai-nilai toleransi sejak awal mahasiswa masuk perguruan tinggi Muhammadiyah, 3) memperkuat nilai toleransi melalui proses perkuliahan, penyelenggaraan, sharing session baik formal maupun informal, dan 4) memberdayakan unit kegiatan mahasiswa dan fasilitas lain yang mendukung proses interaksi mahasiswa multikultural.

Keywords: role; tolerance; Muhammadiyah’s higher-educational institutions

\section{Introduction}

Papua is susceptible to conflict. It is often identified as an area that is prone to war, violence, and underdevelopment. Many also label Papua as a symbol of violence and rebellion (Wekke, 2016). Inequality as another effect of development efforts that result in the community's inability and inability is also one of the factors of the seeds of conflict and strife (alHamid, 2013).

The widespread news about violence perpetrated by armed criminal groups makes many parties unaware that many social and religious organizations have been genuinely building and developing Papua's land. One of the organizations that intensely is Muhammadiyah.

Muhammadiyah's most prominent and iconic role is for its educational and social sector (Pamungkas, 2016). Especially in the West Papua region, Muhammadiyah has hundreds of schools from elementary to high school level. Indeed, there are three Muhammadiyah's highereducational institutions in West Papua; Universitas Muhammadiyah Sorong (UM Sorong), Sorong City, Universitas Pendidikan Muham- 
madiyah Sorong (UNIMUDA) Sorong Regency and Sekolah Tinggi Keguruan dan Ilmu Pendidikan (STKIP) Muhammadiyah Manokwari. These three tertiary institutions are the leading tertiary institutions in West Papua and have produced tens of thousands of alumni throughout Papua land, Papua and West Papua.

Muhammadiyah's higher-educational institutions is expected to have several functions relevant to the progress of the nation and state. Muhammadiyah's higher-educational institutions can prepare a person or group of people to be skilled in a job needed by society in accelerating development; as a means of transmitting life values embodied in positive attitudes that will strengthen the nation's image and culture, high national attitudes, democracy and civilization (Muhmidayeli, 2013; Zuriah, 2014). Stick to the principles; implementing the embodiment of justice in an institutional environment, social empowerment, universality, and human dignity (Nur, 2018). This principles are in line with the statement that the purpose of establishing Muhammadiyah is to realize Islamic society and the enforcement of amar ma'rüf nahì munkar (Darajat, 2017). Muhammadiyah's higher-educational institutions, as a movement for changes in society, requires Islamic higher education to be directed to answer the various problems, to face challenges and to meet needs of the community (Muhmidayeli, 2013).

A large number of Muhammadiyah West Papua college students show that Muhammadiyah has the potential and strategic position in fostering and developing knowledge, art, technology, and tolerance in Indonesia, precisely in Papua. Moreover, the background of students in Muhammadiyah's Higher-educational institutions is mostly non-Muslim. This reality shows that Muhammadiyah is tolerant with other religious students besides Muslims. But, unfortunately, the amount of research related to the role of Muhammadiyah higher-educational institutions in West Papua still lacks. Therefore, this research is expected to contribute to the development of research on the existence of Muhammadiyah in Papua. 
Religious tolerance and feelings of love are the dominant factors for realizing social justice as mandated in Pancasila (Mulia, 2019). Tolerance is the primary concern of Muhammadiyah, especially in Papua. Cases occurred in Papua province,i.e., burning and attack experienced by Muslims during the Eid al-Fitr prayer in Karubaga, Tolikara Regency, Papua Province, on Friday, July 17, 2015, at around 07.00 WIT led to material and moral losses. Substantial losses from such violence always cause damage to facilities, especially public facilities. Also, it brings moral failure as theIndonesia is considered a radical country, which uses acts of violence as a form of change (Widhayat \& Jatiningsih, 2018).

\section{Tolerance}

The term tolerance comes from the Latin from the word "tolerare" which means patiently allowing something. Tolerance in the socio-cultural and religious context means attitudes and actions that prohibit discrimination against groups considered to be different or unacceptable to most people (Bakir, 2009; Digdoyo, 2018). Religious tolerance is an attitude of patience and refraining from disrupting and not harassing religion or belief systems and worship of adherents of other religions (Yasir, 2014), mutual respect, and respect for people of other faiths (Giddens \& Held, 1987, p. 73). In Arabic, the term commonly used as the equivalent of the word tolerance is sammāha or tasammuh, meaning openness or openness in dealing with differences originating from noble personalities (Engineer, 2004, p. 8). Based on some of the above information about tolerance, it can be understood that what is meant by "tolerance" in research is the willingness to respect, respect and accept the existence of other religious people who are actualized in the attitudes and behaviour of both individuals and groups of people without coercion.

There is a causal relationship between harmony and tolerance. Harmony has an impact on tolerance and vice versa, and on the contrary, tolerance produces harmony both related to human relationships (Arifin, 2016). Tolerance between students is to let others have religious freedom 
following article 29 of the 1945 Constitution (Suharyanto, 2013). Besides that, tolerance between students is an attitude of mutual respect and respect for one another's religions. So, tolerance does not mean mixing religious teachings, even the purity of spiritual teachings must be maintained. Be tolerant as long as the understanding is still in the realm of khilafiyah, following the aims of Nationalism and not deviating from Islamic teachings (Saifullah, 2016).

Intolerant attitude will threaten the integrity of pluralistic and multicultural society, and will endanger the state (Akmansyah, 2016). Having a diversified approach and taking reasonable steps is proof that Muhammadiyah education inserts the idea of moderate Islamic culture, which is planted to its students, so they have a modest Islamic character, as is the ideology of the Muhammadiyah struggle itself (Suharto, 2014). This attitude is also shown by Muhammadiyah universities in West Papua, which do not limit themselves to students who are Muslim, even the number of students of other religions is higher than students who are Muslim themselves.

Muhammadiyah's charitable efforts instil several characters starting from primary education in learning including courage, discipline, environmental care, social care, hard work, responsibility, religious, self-confidence, cooperation, honesty, independence, courtesy, obedience to teacher instructions, thoroughness, tolerance and communicative (Utami, 2016). Tolerance values are applied through the implementation of character education through school culture (Rusmayanti \& Mardiyah, 2016).

Education in the tertiary environment can be used as an alternative to prevent the religious radicalism movement, but this fact is not yet felt to be optimal (Sofyan \& Sabardila, 2011). Regarding tolerance in Muhammadiyah's charity efforts, several studies have discussed Muhammadiyah's charity ventures accepting students who are Protestants \& Catholics. Mu'ti and Haq (2009) described in three locations, Kupang (East Nusa Tenggara), Serui (Papua), and Putussibau (West Kalimantan). In the three Muhammadiyah schools that became the focused study, all of them accept 
students who are not only Muslims. This description is complemented by the narrative of Tholkhah (2013). SMA Muhammadiyah Kupang is a case study of how educational institutions are established referring to the Islamic spirit but does not limit the spread of knowledge to Muslim citizens only.

Concerning other people, Muhammadiyah adheres to the principle of fastabiq al-khayrāt and uses the policy of tolerance (Burhani, 2011). Muhammadiyah's cultural da'wa results in accommodative and tolerant attitudes towards the community's cultural diversity (Syamsuddin, 2018). With this condition came the term Christian Muhammadiyah, in a book called Islamology, one of the chapters in the book Muhammadiyah Christians (Tambunan \& Ainuri, 2019) where Protestant and Catholic communities have the opportunity to study in institutions run by Muhammadiyah (Wekke, 2019).

This study examines more in-depth the conditions of the corresponding number of Muslim and non-Muslim students. Besides, to find out how the role of Muhammadiyah universities in West Papua is to maintain religious tolerance in West Papua.

This research is a qualitative study. The research used is descriptive qualitative research. Descriptive qualitative research is research in the form of a case study approach or method. This research was conducted in three Muhammadiyah West Papua universities, namely; Sorong Muhammadiyah University (Sorong UM) Sorong City, Muhammadiyah University of Education (UNIMUDA) Sorong Regency and Muhammadiyah Manokwari College of Teacher Training and Education (STKIP). The respondents to be used in this study were 15 people consisting of 3 leaders, 3 lecturers and 9 students. In this study, two types of data will be used: Interviews and observations. Interviews were conducted with the leaders of Muhammadiyah's higher-educational institutions and several lecturers. The researchers used interviews to determine the approaches and strategies adopted in developing religious tolerance in Muhammadiyah's higher-educational institutions. Observations were made to see the 
relationship between Muslim and non-Muslim students at each of the tertiary institutions and to see student activities carried out by nonMuslim students. This observation was also conducted to look at student data or biodata. This observation was to categorize students based on their religions as well as supporting data in this study.

\section{Religious Identity}

The religious identity of students in West Papua Muhammadiyah University is heterogeneous ranging from Islam, Catholicism, Protestantism, Hinduism, and Buddhism. This situation is understandable because the majority of the population in West Papua is Catholic and Protestant. The condition of diversity in the religious identity of students in each Muhammadiyah's higher-educational institution in West Papua can be fully described in Table 1.

The overall description of the sacred character of students at Muhammadiyah Universities in West Papua can be seen in Table 1. Table 1 shows a description of the religious identity of students in Muhammadiyah's higher-educational institution in West Papua. Where the percentage of Muslim students, around $41 \%$ and non-Muslims as much as $59 \%$. From this data, we can conclude that the religious background of students at Muhammadiyah's higher-educational institutions is very heterogeneous and is trusted by Muslim students and non-Muslim students. This condition shows that Muhammadiyah's higher-educational institutions are not exclusive or even inclusive, where all religious groups feel comfortable and accepted in this college.

This condition is in line with the results of Abdul Mu'ti and Fajar Rizaul Haq's study at Muhammadiyah schools in Christian-majority areas such as Ende, Flores (NTT) and Seruni Papua). In both regions, Muhammadiyah schools accept Christian students. Similar results were also shown in the Tholkhah's study (2013) at Kupang Muhammadiyah High School, where the percentage of Muslim students was $39.54 \%$ and $60.06 \%$ for non-Muslim students. 
Table 1.

The Comparison of Students According to Religious Identity at

West Papua Muhammadiyah's Higher-educational Institutions

\begin{tabular}{clrr}
\hline No. & Students Identity & Frequency & $\%$ \\
\hline 1. & Islam & 5.401 & 40.8 \\
2. & Katolik & 953 & 7.2 \\
3. & Protestant & 6.844 & 51.8 \\
4. & Budha & 1 & 0.0007 \\
5. & Hindu & 8 & 0.006 \\
6. & Konghucu & 0 & 0 \\
7. & others & 0 & 0 \\
\hline & Total & 13.207 & 100 \\
\hline
\end{tabular}

\section{Tolerance Development Approach}

Muhammadiyah's higher-educational institutions realizes that the $\mathrm{di}^{-}$ versity of religious identities in the campus environment makes institutions inevitable to develop approaches and strategies in fostering tolerance and good relations between students, even though they have different religious backgrounds.

Muhammadiyah's higher-educational institutions made some efforts to develop tolerance values, especially for students. In the interviews conducted with the three highest leaders in Muhammadiyah's higher-educational institutions in West Papua, several approaches were concluded.

\section{Social Approach}

Tolerance is a form of respect for fundamental human rights. Tolerance education in Muhammadiyah's higher-educational institutions can be called a social approach to respecting all the differences in society, especially with the diversity of social backgrounds within the tertiary education environment. By realizing the conditions, insights, awareness, and climate of the campus community to be tolerant of fellow human beings. The standard approach is implemented so that conditions in the city remain conducive and avoid conflict triggers such as offence, inequality, and violence. Tolerance is not because you are forced or afraid 
of someone, but is born from your mind, awareness, and desire. The humane approach makes students not easily influenced by the provocation to behave intolerant towards social groups of different religions but, on the contrary, is expected to be a driver to develop a culture of tolerance in the surrounding community (Tholkhah, 2013).

Tolerance defined as letting religious adherents practice their religion, but that does not mean confusing spiritual tenets. Universitas Pendidikan Muhammadiyah Sorong (UNIMUDA), previously known as Sekolah Tinggi Keguruan dan Ilmu Pendidikan (STKIP) Muhammadiyah Sorong, for seven years, received a national grant from Kementrian Riset dan Teknologi Republik Indonesia in the field of tolerance namely "Program Hibah General Education". The long-term goals of "General Education" can help produce graduates who not only have excellent cognitive abilities, but also understand a variety of national problems. Then, expectedly, they will play a role in overcoming the nation's challenges by becoming good and productive citizens. This progress proves that the implementation of tolerance on the Muhammadiyah campuses in the form of a culture of togetherness, unity, and mutual respect was carried out very well.

\section{Cultural Approach}

Local wisdom in the land of Papua received a significant attention. Culturally, Papuans are open to people from outside Papua, especially those they believe are capable of building their community's resources. This condition forms a culture of mutual assistance, concern, and coexistence. Muhammadiyah University itself has been known as a means of building the support of the Papuan people in the field of education. The indigenous people of Papua, who are predominantly Christian, feel comfortable and proud to be part of Muhammadiyah's higher-educational institutions. This feeling of comfort rises because there is no compulsion i.e., to embrace Islam when studying at Muhammadiyah's highereducational institutions. This cultural approach makes students understand all the concepts in Muhammadiyah's higher-educational institutions, 
including a curriculum that covers Al-Islam dan Kemuhammadiyahan/ (Islam and Muhammadiyah values - AIK).

The position of adat (local norms) in the Papuan community is very high. Customary figures are highly valued. Every Papuan child is an indigenous child, which means that every student in the Muhammadiyah's higher-educational institutions is called an indigenous child. In this case, the Rector of Universitas Muhammadiyah Sorong is an advisor to the Moi Community's traditional board. Therefore, the position and direction of the leadership of Muhammadiyah's higher-educational institutions will be strongly heard and heeded.

Muhammadiyah universities pay attention to local wisdom in Papua. The most important thing is not to deviate from Islamic law and norms of decency, especially concerning the appearance and manner of dress. When students present Papuan dance offerings, they must still pay attention to how to behave and dress modestly.

\section{Excellent Service Approach}

In addition to social and cultural approaches, the approach through excellent service is carried out for all students, especially in adminis-trative and academic matters. With the right service approach, students feel privileged regardless of their religious background, likes, and skin colour. They do not feel marginalized. Some students feel inferior at the beginning of the lecture, but eventually, they can interact openly with other students when they get services that do not discriminate.

The heads of Muhammadiyah's higher-educational institutions are figures close to lecturers and students. They can communicate directly to find out all complaints and capture the wishes of every campus citizen. The protect all students without distinguishing their religious origin, ethnicity, and colour. Their open attitudes become examples and role models for students so that they should be guaranteed that they have an open mind and accept all differences. 


\section{Strategies of Tolerance Development}

Based on various observations and interviews, the strategy undertaken by Muhammadiyah's higher-educational institutions in West Papua in developing the application of tolerance values includes: First, the socialization of Muhammadiyah's vision and mission. Muhammadiyah is an inclusive organization. Muhammadiyah's cultural $d a^{w} w a$ results in accommodative and tolerant attitudes towards the cultural diversity of the community (Syamsuddin, 2018). This tolerant and inclusive attitude makes Muhammadiyah's higher-educational institutions open to all religions, classes, and tribes. With this strategy, functionally, Muhammadiyah's higher-educational institutions in West Papua improve the quality of community resources in West Papua.

Second, instilling the value of tolerance from the very beginning of students enrolling Muhammadiyah's higher-educational institutions. This activity can be started with campus introduction activities for new students, including on the campus of Universitas Muhammadiyah Sorong (UM Sorong). This activity is known as AKSIKU (Actualization, Socialization of Campus Life) and MATRAS (Student Ta'arruf Period) activities at the Universitas Pendidikan Muhammadiyah Sorong (UNIMUDA). In this activity, students get an explanation of the rules and policies that exist in Muhammadiyah's higher-educational institutions, especially about the application of Al-Islam dan Kemuhammadiyahan courses for all students. The campus, through this activity, introduces that Muhammadiyah, concerning other people, not only adheres to the principle of fastabiq al-khayrāt but also uses the policy of tolerance (Burhani, 2011).

Third, strengthening the value of tolerance by lecturers in each lecture and face-to-face. The teaching and learning process in the lecture hall is not only a teaching process but also as a means of moral and character education. The message of the importance of understanding tolerance is conveyed at each meeting. In addition to verbal statements, tolerance values are also formed in the learning process. Students mingle in an 
association, division of groups, work assignments with other students who come from different religions and tribes. Differences in student backgrounds in the classroom do not lead to division and hatred in socializing. Tolerance values are implemented through the implementation of character education through campus culture. Lecturers apply character education as a basis for building tolerance values (Rusmayanti \& Mardiyah, 2016).

Fourth, conducting sharing sessions, both formally and informally. This activity is carried out as a forum to "hear" any complaints, opinions, and views of students. Through this activity, the leaders and lecturers of Muhammadiyah's higher-educational institutions become close and understand students' needs.

Fifth, empowering student work units and other facilities that support multicultural student interaction processes. One of the facilities prepared by Universitas Pendidikan Muhammadiyah Sorong (UNIMUDA) in the Sorong Regency is Rumah Multicultural. All students can use college facilities on the condition that when they get together and use it, the group must consist of different religions and tribes. With this rule, students are expected to establish intimacy and closeness with other students who come from different faiths and tribes. Besides, higher-educational institutions prepare internet access for all students.

\section{Conclusion}

Muhammadiyah's higher-educational institutions in West Papua have various religious identity backgrounds. The number of non-Muslim students is more massive than Muslim students. The results showed that Muhammadiyah's higher-educational institutions are inclusive in terms of spiritual understanding. In fostering religious tolerance there are three approaches taken by the three Muhammadiyah higher-educational institutions in West Papua: 1) social approach, 2) cultural approach, and 3) excellent service approaches. The tolerance development approach is social approach, adjusting to the social conditions of the people in West 
Papua. The cultural method is also carried out, which refers to the local wisdom of the Papuan people who uphold customs. Also, the approach to providing the best service, administratively and academically, is provided by staff, lecturers to the highest level of leadership.

The strategies implemented the role includes: 1) disseminating Muhammadiyah's vision and mission, 2) inculcating tolerance values since the beginning of students joining Muhammadiyah highereducational institutions, 3) strengthening tolerance value by lecturing processes, conducting, sharing sessions both formally and informally, and 4) empowering student activity units and other facilities that support multicultural student interaction processes.[w]

\section{References}

Akmansyah, M. (2016). Membangun Toleransi dalam Perspektif Pendidikan Spiritual Sufistik. Kalam, 10(2), 517-536. https://doi.org/ 10.24042/klm.v10i2.12

Arifin, B. (2016). Implikasi Prinsip Tasamuh (Toleransi) dalam Interaksi Antar Umat Beragama. Fikri: Jurnal Kajian Agama, Sosial dan Budaya, 1(2), 391-420.

Bakir, I. (2009). Menebar Toleransi Menyemai Harmoni. Bandung: Rosdakarya.

Burhani, A. N. (2011). Lakum Dīnukum wa-liya Dīnī: The Muhammadiyah's Stance towards Interfaith Relations. Islam and ChristianMuslim Relations, 22(3), 329-342. https://doi.org/10.1080/09596410.2011 .586512

Darajat, Z. (2017). Muhammadiyah dan NU: Penjaga Moderatisme Islam di Indonesia. Hayula: Indonesian Journal of Multidisciplinary Islamic Studies, 1(1), 81-96. https://doi.org/10.21009/hayula.001.1.05

Digdoyo, E. (2018). Kajian Isu Toleransi Beragama, Budaya, dan Tanggung Jawab Sosial Media. Jurnal Pancasila dan Kewarganegaraan, 3(1), 42-59. https://doi.org/10.24269/jpk.v3.n1.2018.pp42-59

Engineer, A. A. (2004). Liberalisasi Teologi Islam: Membangun Teologi Damai dalam Islam. (R. Khamami, Trans.). Yogyakarta: Alenia. 
Giddens, A., \& Held, D. (1987). Perdebatan Klasik dan Kontemporer mengenai Kelompok, Kekuasaan dan Konflik. Jakarta: Rajawali.

al-Hamid, I. (2013). Islam Politik di Papua: Resistensi dan Tantangan Membangun Perdamaian. Millah: Jurnal Studi Agama, 12(2), 441459. https://doi.org/10.20885/millah.volxii.iss2.art7

Mu'ti, A., \& Haq, F. R. (2009). Kristen Muhammadiyah: Konvergensi Muslim dan Kristen dalam Pendidikan. Jakarta: al-Wasat Publishing House.

Muhmidayeli, M. (2013). Kajian Keislaman Berwawasan Kemasyarakatan: Sebuah Telaah Filosofi akan Arah Bangun Pengembangan Keilmuan di PTAI. Jurnal Intelegensia, 1(1).

Mulia, S. M. (2019). Potret Kebebasan Berkeyakinan di Indonesia: Sebuah Refleksi Masa Depan Kebangsaan Indonesia. Nusantara Journal for Southeast Asian Islamic Studies, 14(2), 110-125. Retrieved from http://ejournal.uin-suska.ac.id/index.php/nusantara/article/view/7152

Nur, I. (2018). Eksistensi Lembaga Pendidikan Islam dalam Meretas Potensi Konflik Sosial Budaya. Al-Riwayah: Jurnal Kependidikan, 10(1), 219-242.

Pamungkas, C. (2016). Muslim Papua dan Muslim Pendatang: Pertarungan Identitas antara Ke-indonesia-an dan Ke-papua-an. Jurnal Kawistara, 6(3), 249-264. https://doi.org/10.22146/kawistara.22947

Rusmayanti, M., \& Mardiyah, S. U. K. (2016). Implementasi Pendidikan Karakter di SMK Muhammadiyah 1 Prambanan Klaten. Jurnal Pendidikan Administrasi Perkantoran-S1, 5(2). http://journal.student. uny.ac.id/ojs/ojs/index.php/adp-s1/article/view/4612

Saifullah, I. (2016). Sikap Toleransi dalam Menghadapi Perbedaan Ideologi Keagamaan pada Aktivis IMM di Kota Yogyakarta. Universitas Muhammadiyah Yogyakarta, Yogyakarta.

Sofyan, A., \& Sabardila, A. (2011). Persepsi Mahasiswa terhadap Kata Toleransi Kehidupan Beragama. Jurnal Penelitian Humaniora, 12(2), 182-200.

Suharto, T. (2014). Gagasan Pendidikan Muhammadiyah dan NU sebagai Potret Pendidikan Islam Moderat di Indonesia. Islamica: Jurnal Studi Keislaman, 9(1), 81-109. https://doi.org/10.15642/islamica.2014. 9.1.81-109 
Suharyanto, A. (2013). Peranan Pendidikan Kewarganegaraan dalam Membina Sikap Toleransi antar Siswa. JPPUMA Jurnal Ilmu Pemerintahan dan Sosial Politik Universitas Medan Area, 1(2), 192203. https://doi.org/10.31289/jppuma.v1i2.563

Syamsuddin, M. (2018). Gerakan Muhammadiyah dalam Membumikan Wacana Multikulturalisme: Sebuah Landasan Normatif-Institusional. Jurnal Pemberdayaan Masyarakat: Media Pemikiran dan Dakwah Pembangunan, 1(2), 335-370. https://doi.org/10.14421/jpm.2017. 012-08

Tholkhah, I. (2013). Pendidikan Toleransi Keagamaan: Studi Kasus SMA Muhammadiyah Kupang Nusa Tenggara Timur. Edukasi: Jurnal Penelitian Pendidikan Agama dan Keagamaan, 11(2), 165-181. https://doi.org/10.32729/edukasi.v11i2.432

Utami, R. D. (2016). Membangun Karakter Siswa Pendidikan Dasar Muhammadiyah melalui Identifikasi Implementasi Pendidikan Karakter di Sekolah. Profesi Pendidikan Dasar, 2(1), 32-40. https://doi.org/10.23917/ppd.v2i1.1542

Wekke, I. S. (2016). Harmoni Sosial dalam Keberagaman dan Keberagamaan Masyarakat Minoritas Muslim Papua Barat. Kalam, 10(2), 295-312. https://doi.org/10.24042/klm.v10i2.3

Wekke, I. S. (2019). Kristen Muhammadiyah. https://osf.io/preprints/ inarxiv/ytzb7/

Widhayat, W., \& Jatiningsih, O. (2018). Sikap Toleransi Antarumat Beragama pada SMA Muhammadiyah 4 Porong. Kajian Moral dan Kewarganegaraan, 6(2), 96-610. https://jurnalmahasiswa.unesa.ac.id/ index.php/jurnal-pendidikan-kewarganegaraa/article/view/ 24925/22832

Yasir, M. (2014). Makna Toleransi dalam al-Qur'an. Jurnal Ushuluddin, 22(2), 170-180. https://doi.org/10.24014/jush.v22i2.734

Zuriah, N. (2014). Kajian Etnopedagogi Pendidikan Kewarganegaraan sebagai Wahana Pendidikanbudaya dan Karakter Bangsa di Perguruan Tinggi Muhammadiyah Kota Malang. Jurnal Humanity, 8(1), 170-185. Retrieved from http://ejournal.umm.ac.id/index.php/ humanity/article/view/1986 
This page is intentionally left blank. 